\title{
ARTIKELEN
}

PEER REVIEWED ARTIKEL

\section{Vertrouwen in toezichtsactoren in uitgaansgebieden: een vergelijking tussen politie, portiers en cameratoezicht ${ }^{*}$}

Janne van Doorn \& Jelle Brands

\section{Inleiding}

In de Nederlandse strafrechtspleging zijn verschillende actoren betrokken. Over de functie en taken van deze actoren is veelvuldig geschreven in de literatuur, zo ook waar het gaat om interacties tussen politie en burgers. Binnen laatstgenoemde wordt onder andere gekeken naar de mate waarin het publiek vertrouwen heeft in de politie en hun activiteiten. ${ }^{1}$ Een van de 'vormen' van vertrouwen die onderzocht worden betreft 'interpersoonlijk vertrouwen', gericht op persoonlijk contact en bejegening. Een andere vorm van vertrouwen, en tevens hetgeen waar wij ons in het huidige artikel op richten, betreft 'institutioneel vertrouwen'. Institutioneel vertrouwen is een weerspiegeling van wat we zouden kunnen duiden als een functiewaardering van de politie; de mate waarin de politie competent wordt geacht om te acteren. ${ }^{2}$ Het is van belang om vertrouwen onder burgers in kaart te brengen, omdat de mate waarin burgers de toezichthouder vertrouwen samenhangt met de bereidheid om de aanwezigheid van deze actoren te accepteren en met hen samen te werken. Dat bepaalt vervolgens de mate of het vermogen van de actor om controle uit te oefenen. ${ }^{3}$ Kortom, een gemis aan vertrouwen zou de effectiviteit en legitimiteit van een toezichtsactor kunnen schaden. ${ }^{4}$

* Dr. Janne van Doorn en dr. Jelle Brands zijn beiden universitair docent aan het Instituut voor Strafrecht \& Criminologie van de Universiteit Leiden.

1 Zie voor een goed overzicht I.Y. Sun, Y. Wu \& R. Hu, 'Public assessments of the police in rural and urban China:A theoretical extension and empirical investigation', British Journal of Criminology 2013, 53, p. 643-664; J. Jackson \& B. Bradford, 'What is trust and confidence in the police?', Policing 2010, 4, p. 241-248.

2 B. Bradford \& J. Jackson, 'Trust and confidence in the police: A conceptual review', SSRN Electronic Journal 2010, p. 1-15.

3 Jackson \& Bradford 2010; T.R. Tyler, 'Public trust and confidence in legal authorities: What do majority and minority group members want from the law and legal institutions?', Behavioral Sciences and the Law 2001, 19, p. 215-235.

4 Jackson \& Bradford 2010; J. Sunshine \& T.R. Tyler, 'The role of procedural justice and legitimacy in shaping public support for policing', Law \& Society Review 2003, 37, p. 513-548. 
Tegelijkertijd is het niet enkel de politie (meer) die toezicht houdt in onze samenleving. Onderzoekers spreken ook wel van de 'pluralisering van toezicht', waarbij private beveiligers en technische surveillance in de vorm van bijvoorbeeld cameratoezicht (ook wel CCTV genoemd) in toenemende mate taken van de politie overnemen. ${ }^{5}$ McCahill beargumenteert zelfs dat de 'emergence of a pluralized and differentiated patchwork of policing has been reinforced by the introduction of closed circuit television (CCTV) surveillance systems which operate across both state and extra-state institutions and are monitored by a diverse range of actors' (p. 200). Aangezien de autoriteit om toezicht te houden meer verdeeld raakt onder een verscheidenheid aan publieke en private actoren, is het opvallend dat er nog maar relatief weinig onderzoek is gedaan naar het (institutionele) vertrouwen dat burgers hebben in dergelijke (andere) actoren, hoe dit zich verhoudt met vertrouwen in de politie, en hoe dit vertrouwen uitsplitst naar verschillende groepen in onze samenleving. ${ }^{6}$ Wanneer vertrouwen niet of nauwelijks aanwezig is bij sommige van de actoren, kunnen er vraagtekens gezet worden bij de eerdergenoemde verschuiving van taken van publieke naar private en/of technologische actoren.

Dit artikel beoogt invulling te geven aan de hiervoor genoemde onderzoekslacune door middel van onderzoek binnen de context van het stedelijk nachtleven. De stedelijke nacht alsmede de stedelijke uitgaansgebieden worden vaak beschouwd als een tijdruimte waar behoefte is aan toezicht en controle vanwege (overmatige) consumptie van alcohol en drugs en de overlast die daaraan gekoppeld wordt, zoals opstootjes en geluidsoverlast voor omwonenden. ${ }^{7}$ Met andere woorden, het vertrouwen in toezichtsactoren kan met name in deze context een belangrijke rol spelen. In het nachtleven zien we bovendien ook een duidelijke uitbreiding en diversificatie van toezichtsactoren. ${ }^{8}$ Het huidige onderzoek richt zich specifiek op drie toezichtsactoren die veelvuldig binnen de (inter)nationale wetenschappelijke en beleidsliteratuur besproken worden in relatie tot uitgaansproblematiek: de

5 T. Jones \& T. Newburn, 'Understanding plural policing', in: T. Jones \& T. Newburn (red.), Plural policing: a comparative perspective, New York: Routledge 2006, p. 1-11; M. McCahill, 'Plural policing and CCTV surveillance', in: M. Deflem \& J.T. Ulmer (red.), Surveillance and governance: Crime control and beyond, Emerald Group Publishing Limited 2008, p. 199-219; T. Newburn, 'The commodification of policing: Security networks in the late modern city', Urban Studies 2001, 38, p. 829-848; J. de Waard \& R. van Steden, 'De opmars van de private veiligheidszorg: Een nationaal en internationaal perspectief', Justitiële Verkenningen 2012, 38, p. 9-23; R. van Steden \& H. Boutellier, 'Alles onder controle: De privatisering van de veiligheid in Nederland', Tijdschrift voor de Politie 2008, 70, p. 26-27; R. Yarwood, 'The geographies of policing', Progress in Human Geography 2007, 31, p. 447-465.

6 Maar zie E. Saarikkomäki, 'Young people's conceptions of trust and confidence in the crime control system: Differences between public and private policing', Criminology \& Criminal Justice 2017, 18, p. 156-172.

$7 \quad$ P. Hadfield, S. Lister \& P. Traynor, “This town's a different town today”: Policing and regulating the night-time economy', Criminology \& Criminal Justice 2009, 9, p. 465-485; R. Shaw, 'Neoliberal subjectivities and the development of the night-time economy in British cities', Geography Compass 2010, 4, p. 893-903.

8 P. Hadfield \& F. Measham, 'The outsourcing of control: Alcohol law enforcement, private-sector governance and the evening and night-time economy', Urban Studies 2015, 52, p. 517-537. 
politie, portiers en cameratoezicht. ${ }^{9}$ De volgende onderzoeksvragen staan centraal:

1 In hoeverre hebben jongeren vertrouwen in de politie, portiers en cameratoezicht?

2 In hoeverre verschilt dit vertrouwen in de politie, portiers en cameratoezicht van elkaar?

3 In hoeverre is dit vertrouwen in de politie, portiers en cameratoezicht verschillend voor groepen gebaseerd op demografische en contextuele variabelen?

Om deze vragen te beantwoorden gebruiken we data verkregen uit een enquête verspreid onder scholieren en studenten uit Utrecht en Rotterdam ( $n=894)$. Alvorens deze data in meer detail te bespreken, zetten we eerder onderzoek uiteen dat vertrouwen in de genoemde toezichtsactoren apart heeft onderzocht, gevolgd door demografische en contextuele voorspellers van vertrouwen.

\section{Vertrouwen in politie, portiers en cameratoezicht: een overzicht}

Uit eerder (inter)nationaal onderzoek verricht naar vertrouwen in de politie kan opgemaakt worden dat het vertrouwen in de politie in (westerse) Noord-Europese landen aanzienlijk is. ${ }^{10}$ In Nederland wordt er zelfs een geleidelijke toename in het vertrouwen in de politie gerapporteerd: van 6,1 in 2012 naar 6,5 in 2017.11 Veel minder studies bestuderen beoordelingen van private beveiliging zoals portiers. Op basis van de relatief schaarse hoeveelheid onderzoek naar private beveiliging zien we dat er een algemeen positieve perceptie van beveiligers is onder universiteitsstudenten en een meer gemiddeld niveau van vertrouwen onder burgers. ${ }^{12}$ Kortom, er kan voorzichtig gesteld worden dat mensen min of meer neutraal zijn als het gaat om het vertrouwen in deze specifieke toezichtsactor.

9 Omdat institutioneel vertrouwen zich richt op competenties van de actor, leent deze vorm van vertrouwen zich dus goed om bestudeerd te worden voor zowel publieke en private als technologische toezichtsactoren.

10 E. Blankenburg, 'Patterns of legal culture: The Netherlands compared to neighboring Germany', The American Journal of Comparative Law 1998, 46, p. 1-41; J. Kääriäinen, 'Trust in the Police in 16 European countries', European Journal of Criminology 2007, 4, p. 409-435.

11 Centraal Bureau voor de Statistiek 2018, StatLine - Burgers en Politie, via http://statline.cbs.nl/ Statweb/publication/?DM=SLNL\&PA=81929NED\&D1=50\&D2=0-6\&D3=0\&D4=a\&HDR=G1,G3\& $\mathrm{STB}=\mathrm{T}, \mathrm{G} 2 \& \mathrm{VW}=\mathrm{T}$. Het vertrouwen in de politie wordt gemeten via de volgende stellingen: 'Als het er echt om gaat zal de politie het uiterste doen om je te helpen' en 'Als het er echt om gaat dan is de politie er voor je' (helemaal eens $=4$; mee eens $=3$; niet mee eens en niet mee oneens = 2 ; mee oneens $=1$; helemaal mee oneens $=0$; geen antwoord $=$ missing). De waarden worden bij elkaar opgeteld en vermenigvuldigd met 10/8. De schaalscore loopt van 0 tot 10 . Hoe hoger de score, hoe groter het vertrouwen in de politie.

12 A. Moreira, C. Cardoso \& M.K. Nalla, 'Citizen confidence in private security guards in Portugal', European Journal of Criminology 2015, 12, p. 208-225; M.K. Nalla \& C.G. Heraux, 'Assessing goals and functions of private police', Journal of Criminal Justice 2003, 31, p. 237-247; R. van Steden \& M.K. Nalla, 'Citizen satisfaction with private security guards in the Netherlands: Perceptions of an ambiguous occupation', European Journal of Criminology 2010, 7, p. 214-234; R. van Steden, M. Roelofs \& M.K. Nalla, 'Burgers over beveiligers. Een kwantitatief onderzoek naar percepties, verwachtingen en oordelen', Tijdschrift voor Veiligheid 2009, 8, p. 3-21. 
Een studie naar het verschil in vertrouwen tussen de politie en private beveiligers, op basis van kwalitatieve interviews met jongeren uit Helsinki, toont dat deelnemers de politie doorgaans als vriendelijker, voorspelbaarder, humoristischer en professioneler beoordelen dan private beveiligers. ${ }^{13}$ De studie meldt ook dat de jongeren (en in het bijzonder etnische minderheden) de neutraliteit van beveiligers meer in twijfel trekken dan de neutraliteit van politieagenten. Toch rapporteert de studie ook positieve ontmoetingen met beveiligers en negatieve ontmoetingen met de politie, waardoor het vorenstaande genuanceerd wordt. Interessant is dat deelnemers in het algemeen vertrouwen hadden in zowel politie als beveiligers en dat een paar deelnemers een zeer laag vertrouwen hadden in beide actoren.

Naar ons weten is er geen vergelijkend onderzoek uitgevoerd voor cameratoezicht waarin vertrouwen in deze actor vergeleken wordt met vertrouwen in politie en/ of private beveiliging. Studies die specifiek onderzoek doen naar deze actor tonen aanzienlijke algemene steun vanuit de bevolking voor (de installatie van) cameratoezicht. ${ }^{14}$ Onderzoek meldt bijvoorbeeld dat $82 \%$ van de ondervraagde participanten blij was met het vooruitzicht van de installatie van een nieuw camerasysteem. ${ }^{15}$ Andere studies tonen dat de installatie van cameratoezicht werd verwelkomd door respectievelijk ongeveer $90 \%^{16}$ en $64 \%^{17}$ van de participanten. Tegelijkertijd verschijnen er sinds de grootschalige introductie van CCTV ook meer kritische studies die het functioneren van het instrument in twijfel trekken. Zo stelt Webster ${ }^{18}$ bijvoorbeeld dat '[p]resumably, as time passes and greater awareness of the limitations and implications of CCTV use becomes common knowledge public support will diminish' (p. 18). Ellis en collega's vinden het dan ook 'verbazingwekkend' dat er nog maar weinig onderzoek gedaan is naar vertrouwen in surveillancesystemen, waaronder CCTV. Zij beargumenteren dat 'trust is clearly one of the central components of surveillance systems' (p. 2). De weinige studies die verder gaan dan algemene percepties van cameratoezicht zoals geschetst door voornoemde peilingen en enquêtes onder het algemene publiek, lijken te suggereren dat cameratoezicht ook wantrouwen kan opwekken vanwege de beperkte mogelijkheid om bij criminaliteit in te grijpen en het te voorkomen. ${ }^{19}$ Een recent

13 Saarikkomäki 2017.

14 M. Gill, J. Bryan \& J. Allen, 'Public perceptions of CCTV in residential areas: "It is not as good as we thought it would be"', International Criminal Justice Review 2007, 17, p. 304-324.

15 A. Spriggs e.a., Public attitudes towards CCTV: Results from the pre-intervention public attitude survey carried out in areas implementing CCTV, Londen: Home Office 2005.

16 T. Honess \& E. Charman, Closed circuit television in public places: Its acceptability and perceived effectiveness, Londen: Home Office 1992.

17 T. Bennett \& L. Gelsthorpe, 'Public attitudes towards CCTV in public places', Studies on Crime and Crime Prevention 1996, 5, p. 72-90.

18 W. Webster, 'CCTV policy in the UK: Reconsidering the evidence base', Surveillance and Society 2009, 6, p. 10-22. Zie daarnaast J. Ditton, 'Public support for town centre CCTV schemes: Myth or reality?', in: C. Norris, J. Moran \& G. Armstrong (red.), Surveillance, closed circuit television and social control, Aldershot: Ashgate 1998, p. 221-228.

19 D. Ellis, D. Harper \& L. Tucker, 'The dynamics of impersonal trust and distrust in surveillance systems', Sociological Research Online 2013, 18, p. 1-12; D. Neyland, Privacy, surveillance and public trust, Londen: Palgrave Macmillan 2006. 
onderzoek dat is gebaseerd op kwantitatief bewijs uit Thailand meldt ook dat niveaus van institutioneel vertrouwen in cameratoezicht eigenlijk matig tot laag zijn. ${ }^{20}$

\section{Demografische en contextuele voorspellers van vertrouwen}

Omdat we in ons onderzoek niet enkel een vergelijking willen maken in vertrouwen tussen actoren, maar tevens willen onderzoeken in hoeverre dit vertrouwen verschillend is voor verschillende groepen, is het van belang om de literatuur omtrent demografische en contextuele voorspellers van vertrouwen te raadplegen. Daarin baseren we ons met name op de politieliteratuur, omdat vertrouwen een intensief onderzocht onderwerp is binnen deze literatuur, en in mindere mate in de literatuur over private beveiliging en cameratoezicht (in deze literatuur gaat het meer algemeen over percepties). Binnen de politieliteratuur zien we dat er enige consensus is in demografische en contextuele voorspellers van vertrouwen in de politie: met name jongeren, mensen met een niet-westerse achtergrond en mensen met een lager inkomen lijken over het algemeen minder tevreden te zijn over de politie. ${ }^{21}$ Onderzoek naar de rol van geslacht en het woonachtig zijn in stad of achterland toont gemixte resultaten in relatie tot vertrouwen in de politie. ${ }^{22}$ Daarnaast, eerder slachtofferschap (iemand die in de afgelopen twaalf maanden slachtoffer is geweest van een misdrijf) verminderde het vertrouwen in de politie, terwijl vrijwillige contacten met de politie het vertrouwen in de politie juist vergroot. ${ }^{23}$ Er wordt gesteld dat wanneer mensen zich geïnformeerd voelen over politieactiviteiten en regelmatig politiepatrouilles zien, zij een positiever oordeel hebben over de effectiviteit en betrokkenheid van de politie. ${ }^{24} \mathrm{Op}$ basis van het voorgaande kan verwacht worden dat mensen die in een grote gemeente wonen en vaker worden blootgesteld aan intensief gecontroleerde tijdruimten (zoals stedelijke uitgaansgebieden), ook de aanwezigheid van toezichtsactoren meer waarderen. Wanneer we de literatuur omtrent percepties (dus niet specifiek vertrouwen) van private beveiliging in ogenschouw nemen, lijkt daaruit tevens naar voren te komen dat gender en etniciteit van invloed zijn. ${ }^{25}$ Of de hiervoor besproken voorspellers ook voorspellers zijn van vertrouwen in portiers en cameratoezicht is onduidelijk. Anders gezegd, of bepaalde voorspellers het soort actor overstijgen, is een van de vragen die zal worden beantwoord in het huidige onderzoek.

20 J. Trimek, 'Public confidence in CCTV and fear of crime in Bangkok, Thailand'. International Journal of Criminal Justice Sciences 2016, 11, p. 17-29.

21 B. Brown \& B.R. Benedict, 'Perceptions of the police: Past findings, methodological issues, conceptual issues and policy implications', Policing: An International Journal of Police Strategies \& Management 2002, 25, p. 543-580; Kääriäinen 2007; L. Ren e.a., 'Linking confidence in the police with the performance of the police: Community policing can make a difference', Journal of Criminal Justice 2005, 33, p. 55-66.

22 Brown \& Benedict 2002; Ren e.a., 2005.

23 Ren e.a. 2005.

24 B. Bradford, J. Jackson \& E.A. Stanko, 'Contact and confidence: Revisiting the impact of public encounters with the police', Policing and Society 2009, 19, p. 20-46. 


\section{Methode}

\section{Participanten}

Het onderhavige onderzoek is gebaseerd op vragen uit een enquête naar veiligheidsbeleving en toezicht in uitgaansgebieden. De participanten van de enquête betroffen jongeren die onderwijs volgden in de steden Utrecht en Rotterdam (maar niet noodzakelijkerwijs in deze steden woonden).

Ons resultaat is gebaseerd op een bruikbare respons van 894 personen (van de 1457), waarin beide geslachten goed vertegenwoordigd waren (57\% vrouwelijk). De gemiddelde leeftijd was 20,29 jaar (SD = 3,29). ${ }^{26}$ Rekening houdend met het feit dat de minimale drinkleeftijd op het moment van de studie 16 jaar en ouder was, werden studenten onder deze leeftijd uitgesloten van deze studie. Van de participanten woont $52 \%$ in een grote Nederlandse gemeente ( $\geq 100.000$ inwoners ${ }^{27}$ ), $48 \%$ in een kleine(re) Nederlandse gemeente. ${ }^{28}$ Van de participanten had $79 \%$ geen migratieachtergrond (dat wil zeggen, het geboorteland van beide ouders is Nederland) en had $21 \%$ had wel een migratieachtergrond (ten minste één ouder is in het buitenland geboren; volgens definitie $\left(\mathrm{CS}^{29}\right)$. Van de participanten gaf $52 \%$ aan de afgelopen drie jaar slachtoffer te zijn geweest tijdens het uitgaan. ${ }^{30}$ Tot slot gaf $38 \%$ aan ongeveer één keer per maand of minder uit te gaan, $27 \%$ ongeveer eens per twee weken en $35 \%$ ongeveer één keer per week of meer.

\section{Instrumentarium}

Om de mate van vertrouwen in toezichtsactoren in kaart te brengen werden de volgende twee stellingen aan participanten voorgelegd: (1) 'Ik heb in het algemeen veel vertrouwen in [actor]', en (2) 'Ik heb veel vertrouwen in [actor] wanneer zij ingrijpen bij incidenten in een uitgaansgebied'. Gevraagd werd in hoeverre zij het met deze stellingen eens waren op een schaal van 1 (helemaal mee oneens) tot 7 (helemaal mee eens). Voor cameratoezicht is de tweede vraag iets anders gesteld, rekening houdend met het feit dat cameratoezicht zelf niet (rechtstreeks) kan ingrijpen als zich een incident voordoet: 'Ik heb veel vertrouwen in cameratoezicht wanneer ik een incident zie in een uitgaansgebied'. We hebben gemiddelde scores gemaakt van de twee vertrouwensitems voor de politie (Cronbach's $\alpha=, 88$ ), portiers (Cronbach's $\alpha=, 84$ ) en cameratoezicht (Cronbach's $\alpha$ $=, 91)$.

27 Platform 31 2018, Midsize NL, via www.platform31.nl/wat-we-doen/programmas/ruimte-eneconomie/midsize-nl/kenmerken-middelgrote-stad.

28 Er waren vijf missende waarden op deze variabele.

29 www.cbs.nl/nl-nl/achtergrond/2016/47/afbakening-generaties-met-migratieachtergrond.

30 Hieronder vallen: nafluiten/naroepen, aanstaren, intimideren, uitschelden, achtervolgen/in de gaten houden, vechtpartij of handtastelijkheden/ongewenste intimiteiten. 


\section{Analyse}

Om de eerste twee onderzoeksvragen te beantwoorden zal allereerst, middels $t$ toetsen, op algemeen niveau gekeken worden naar de mate van vertrouwen in de toezichtsactoren en vervolgens of die mate van vertrouwen verschilt van de andere toezichtsactoren. Om de rol van verschillende demografische en contextuele variabelen in kaart te brengen (derde onderzoeksvraag), zal (1) middels variantieanalyses gekeken worden of de mate van vertrouwen per actor verschilt tussen bepaalde (demografische en contextuele) groepen, en (2) middels gepaarde $t$-toetsen gekeken worden of de mate van vertrouwen tussen actoren verschilt binnen iedere (demografische en contextuele) groep. Hierbij is ervoor gekozen om de verschillende gepaarde $t$-toetsen samenvattend op te schrijven door de laagste significante $t$-waarde en bijbehorende $p$-waarde te rapporteren.

\section{Resultaten}

\section{Vertrouwen in toezichtsactoren}

In figuur 1 worden de scores voor vertrouwen in de drie toezichtsactoren weergegeven. Daarbij kan gesteld worden dat het vertrouwen in de politie aanzienlijk was, met een gemiddelde van $4,53(S D=1,43)$. Ook het vertrouwen in portiers was aanzienlijk, maar met een gemiddelde van $4,34(S D=1,49)$ iets lager. Voor beide verschillen de gemiddelde waarden ook significant (positief) van het midden (4) van de schaal. ${ }^{31} \mathrm{Al}$ met al kan dan ook gesteld worden dat participanten positief waren in hun vertrouwen in zowel de politie als portiers. Figuur 1 laat tegelijkertijd zien dat vertrouwen in cameratoezicht lager lag, met een gemiddelde van $3,23(S D=1,41)$. Ook blijkt voor CCTV het gerapporteerde vertrouwen significant (negatief) af te wijken van het midden (4) van de schaal. ${ }^{32}$

Het voorgaande sorteert ook al voor op de tweede onderzoeksvraag van deze studie: in hoeverre verschillen vertrouwen in de politie, portiers en cameratoezicht van elkaar? Wanneer de hiervoor beschreven waarden voor vertrouwen in de drie toezichtsactoren op basis van een gepaarde $t$-toets met elkaar vergeleken worden, dan blijkt het gerapporteerde vertrouwen tussen de actoren in alle gevallen significant van elkaar te verschillen: participanten hadden significant meer vertrouwen in de politie dan in portiers, waar zij weer significant meer vertrouwen in hadden dan in cameratoezicht. Een logisch gevolg is dat participanten ook significant meer vertrouwen hadden in de politie dan in cameratoezicht. ${ }^{33} \mathrm{Op}$ basis van het voorgaande lijken participanten groter vertrouwen te rapporteren in menselijke toezichtsactoren dan in een technische toezichtsactor.

31 Wanneer er gesproken wordt over een verschil, bedoelen wij een statistisch significant verschil. Wanneer gesproken wordt over de afwezigheid van een verschil, dan doelen wij op de afwezigheid van een statistisch significant verschil.

32 Politie: $t(893)=11,23, p<, 001$; portiers: $t(893)=6,90, p<, 001)$; cameratoezicht: $t(893)=$ $-16,20, p<, 001$.

33 Politie versus portiers: $t(893)=3,40, p=, 001$; portiers versus cameratoezicht: $t(893)=17,86, p$ $<, 001$; politie versus cameratoezicht: $t(893)=23,04, p<, 001)$. 
Figuur 1 Scores voor vertrouwen in de politie (boven), cameratoezicht (midden) en portiers (onder). De schalen laten stapjes van 0,5 zien, omdat het samengestelde scores betreft (zie methodesectie)

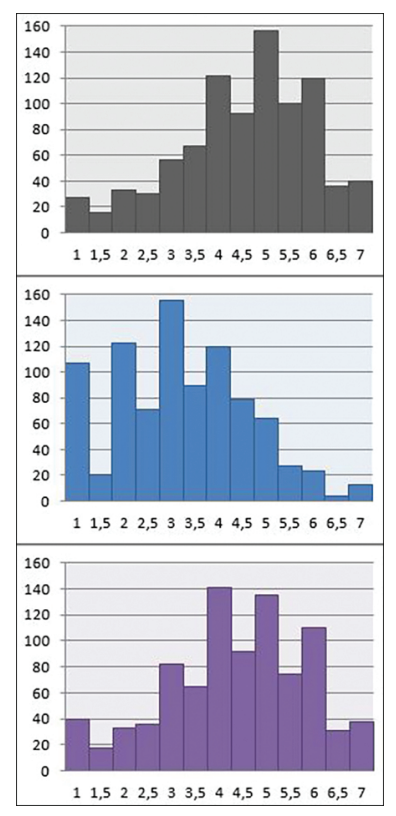

Demografische en contextuele voorspellers van vertrouwen

De derde onderzoeksvraag richt zich op de mate waarin het vertrouwen in de politie, portiers en cameratoezicht verschillend is wanneer rekening wordt gehouden met een aantal demografische en contextuele variabelen. Daarbij worden telkens eerst resultaten gepresenteerd die per actor aantonen of er verschillen bestaan op basis van geslacht, leeftijd, migratieachtergrond, grootte gemeente, eerder slachtofferschap en frequentie van uitgaan. Daarna wordt telkens gekeken of het relatieve vertrouwen tussen actoren verschillend is voor de groepen binnen geslacht, leeftijd, migratieachtergrond, grootte gemeente, eerder slachtofferschap en frequentie van uitgaan. Een overzicht van alle gemiddelden is te vinden in tabel 1.

\section{- Geslacht}

Per actor. Mannen hadden meer vertrouwen in cameratoezicht dan vrouwen, terwijl vrouwen meer vertrouwen hadden in portiers dan mannen. Voor politie werd geen verschil gevonden in termen van geslacht. ${ }^{34}$

Tussen actoren. Mannen hadden meer vertrouwen in de politie dan in portiers, in wie zij weer meer vertrouwen hadden dan in cameratoezicht. Vrouwen hadden meer vertrouwen in de politie en portiers in vergelijking met cameratoezicht. Er 
was geen significant verschil tussen vertrouwen in de politie en portiers onder vrouwen. ${ }^{35}$

\section{- Leeftijd}

Per actor. Resultaten toonden een significant verband tussen leeftijd en vertrouwen in de politie en portiers, maar niet voor vertrouwen in cameratoezicht. Participanten in de leeftijd 20-21 jaar hadden het meeste vertrouwen in de politie in vergelijking met participanten in de leeftijd 16-17 en 18-19. Participanten in de leeftijd van 22 of ouder verschilden qua vertrouwen in de politie niet van de andere leeftijdsgroepen. Daarnaast, qua vertrouwen in portiers werd enkel gevonden dat participanten in de leeftijd 16-17 meer vertrouwen hadden dan participanten in de leeftijd 22 en ouder. ${ }^{36}$

Tussen actoren. Participanten in de leeftijd 16-17 en 18-19 hadden meer vertrouwen in de politie en portiers dan in cameratoezicht. Er was geen significant verschil tussen vertrouwen in de politie en portiers voor deze leeftijdsgroepen. Participanten in de leeftijd 20-21 en 22 en ouder hadden het meeste vertrouwen in de politie, gevolgd door portiers, in wie ze weer meer vertrouwen hadden dan in cameratoezicht. ${ }^{37}$

\section{- Migratieachtergrond ${ }^{38}$}

Per actor. Participanten zonder migratieachtergrond hadden meer vertrouwen in de politie dan participanten met migratieachtergrond. Er werden geen verschillen gevonden op vertrouwen in cameratoezicht en portiers tussen participanten met en zonder migratieachtergrond. ${ }^{39}$

Tussen actoren. Participanten zonder migratieachtergrond hadden het meeste vertrouwen in de politie, gevolgd door portiers, in wie ze weer meer vertrouwen hadden dan in cameratoezicht. Participanten met migratieachtergrond hadden meer vertrouwen in de politie en portiers dan in cameratoezicht. Er was geen significant verschil tussen vertrouwen in de politie en portiers. ${ }^{40}$

35 Respectievelijk: alle $t^{\prime}$ s > 3,65, $p$ 's <,001; alle $t^{\prime}$ 's $>17,84$, $p$ 's $<, 001 ; t=1,16, p=, 249$.

36 Doordat er binnen deze variabele sprake is van meer dan twee groepen, zijn aanvullend op de variantieanalyse Tukey post-hoc toetsen uitgevoerd om verschillen tussen leeftijdsgroepen verder te duiden. Deze analyse geeft enkel $p$-waarden. Politie: $F(3,890)=5,24, p=, 001 ; p$ 's <,006, alle andere $p$ 's > 211. Portiers: $F(3,890)=3,55, p=, 014 ; p=, 013$, alle andere $p$ 's >,088. Cameratoezicht: $F(3,890)=0,21, p=, 889$.

37 Respectievelijk: alle $t$ 's > 8,57, p's <,001); alle t's > 1,57, p's >,119; alle $t$ 's > 3,86, p's <,001.

38 Omdat er sprake is van ongelijke groepsgrootten binnen deze variabelen, en Levene's test voor gelijke varianties werd geschonden op de variabelen 'vertrouwen in politie' $(p=, 049)$ en 'vertrouwen in portiers' $(p=, 044)$, is er tevens een non-parametrische Kruskal-Wallistoets uitgevoerd. Hieruit kwam een gelijk resultaat naar voren: enkel 'vertrouwen in politie' verschilde tussen participanten zonder migratieachtergrond versus met migratieachtergrond.

39 Respectievelijk: politie: $F(1,892)=6,32, p=, 012$; cameratoezicht $F(1,892)=2,83, p=$,093; portiers: $F(1,892)=2,97, p=, 085)$.

40 Respectievelijk: alle $t$ 's > 3,30, $p$ 's < ,001; alle $t$ 's > 5,61, $p$ 's < ,001; $t=1,02, p=, 310$. 


\section{- Grootte gemeente}

Per actor. Participanten woonachtig in een kleine gemeente hadden meer vertrouwen in portiers dan participanten woonachtig in een grote gemeente. Er werd geen verschil gevonden op vertrouwen in de politie en cameratoezicht. ${ }^{41}$

Tussen actoren. Participanten woonachtig in een grote gemeente hadden het meeste vertrouwen in de politie, gevolgd door portiers. Ze hadden het minste vertrouwen in cameratoezicht. Participanten woonachtig in een kleine gemeente hebben meer vertrouwen in de politie en portiers dan in cameratoezicht. Er was geen significant verschil tussen vertrouwen in de politie en vertrouwen in portiers. $^{42}$

\section{- Eerder slachtofferschap}

Per actor. Participanten die de afgelopen drie jaar eerder slachtoffer zijn geweest tijdens het uitgaan, toonden een lager vertrouwen in de politie en cameratoezicht dan participanten die niet eerder slachtoffer zijn geweest. Er werd geen significant verschil gevonden op vertrouwen in portiers. ${ }^{43}$

Tussen actoren. Eerdere slachtoffers hadden een lager vertrouwen in cameratoezicht dan in de politie en portiers. Er was geen significant verschil tussen vertrouwen in de politie en portiers. Participanten die niet eerder slachtoffer zijn geweest, toonden het meeste vertrouwen in de politie, gevolgd door portiers, die weer werden opgevolgd door cameratoezicht. ${ }^{44}$

\section{- Frequentie van uitgaan ${ }^{45}$}

Per actor. Er waren geen significante verschillen in vertrouwen in politie, portiers en cameratoezicht tussen participanten die veel of weinig uitgaan. ${ }^{46}$

Tussen actoren. Alle groepen hadden een lager vertrouwen in cameratoezicht dan in de politie en portiers. Er was geen significant verschil tussen vertrouwen in de politie en portiers. ${ }^{47}$

\section{Conclusie}

Dit artikel had tot doel een vergelijkende analyse te maken van vertrouwen in verschillende toezichtsactoren in het nachtleven, namelijk de politie, portiers en cameratoezicht. Meer specifiek werd gekeken hoe groot het vertrouwen in deze

41 Respectievelijk: portiers: $F(1,887)=7,38, p=, 007$; politie: $F(1,887)=0,01, p=, 914$; cameratoezicht: $F(1,887)=0,08, p=, 772$.

42 Respectievelijk: alle $t$ 's $>3,97, p$ 's < ,001; alle $t^{\prime}$ 's $>14,81$, $p$ 's $<, 001 ; t=0,52, p=, 600$.

43 Respectievelijk: politie: $F(1,892)=10,18, p=, 001$; cameratoezicht: $F(1,892)=30,34, p<, 001$; portiers: $F(1,892)=1,11, p=, 292$.

44 Respectievelijk: alle $t$ 's > 14,48, $p$ 's < ,001; $t=1,11, p=, 267$; alle $t$ 's $>4,19$, p's < 001 .

45 Deze variabele bevatte 827 participanten; aan 67 participanten is niet gevraagd hoe vaak ze in het algemeen uitgaan omdat zij hadden aangegeven de afgelopen drie maanden niet uit te zijn geweest.

46 Alle $F^{\prime}$ s $(2,824)<1,77, p^{\prime}$ s $>, 171$.

47 Respectievelijk: alle $t$ 's $>9,62$, $p$ 's < ,001; alle $t$ 's $<1,89$, p's > ,061. 
Tabel 1 Gemiddelden (en standaard deviaties) van vertrouwen in toezichtactoren

\begin{tabular}{|c|c|c|c|c|}
\hline & & $\begin{array}{l}\text { Vertrouwen } \\
\text { politie }\end{array}$ & $\begin{array}{l}\text { Vertrouwen } \\
\text { cameratoezicht }\end{array}$ & $\begin{array}{l}\text { Vertrouwen } \\
\text { portiers }\end{array}$ \\
\hline Totale score & & $4,53(I, 43)_{\mathrm{a}}$ & $3,23(I, 4 I)_{b}$ & $4,34(I, 49)_{\mathrm{c}}$ \\
\hline \multirow[t]{2}{*}{ Geslacht } & Man & $4,5 \mathrm{I}(1,52)_{\mathrm{a}}$ & $3,4 \mathrm{I}(1,56)_{\mathrm{b}}$ & $4,17(1,63)_{\mathrm{c}}$ \\
\hline & Vrouw & $4,55(1,36)_{a}$ & $3,10(1,26)_{\mathrm{d}}$ & $4,47(1,36)_{a}$ \\
\hline \multirow[t]{4}{*}{ Leeftijd } & $16-17$ & $4,36(I, 47)_{a}$ & $3,24(1,38)_{c}$ & $4,54(1,39)_{a}$ \\
\hline & $18-19$ & $4,36(1,49)_{\mathrm{a}}$ & $3,18(1,41)_{c}$ & $4,43(I, 5 I)_{a d}$ \\
\hline & $20-21$ & $4,84(I, 2 I)_{b}$ & $3,25(1,33)_{c}$ & $4,37(1,46)_{\mathrm{ad}}$ \\
\hline & $\geq 22$ & $4,60(I, 46)_{a b}$ & $3,27(1,48)_{c}$ & $4,12(1,53)_{\mathrm{d}}$ \\
\hline \multirow[t]{2}{*}{ Migratieachtergrond } & Zonder & $4,60(1,40)_{a}$ & $3,19(1,39)_{\mathrm{c}}$ & $4,38(1,46)_{b}$ \\
\hline & Met & $4,30(1,53)_{b}$ & $3,39(1,49)_{\mathrm{c}}$ & $4,17(1,60)_{b}$ \\
\hline \multirow[t]{2}{*}{ Grootte gemeente } & Groot & $4,54(I, 43)_{a}$ & $3,25(I, 42)_{b}$ & $4,22(I, 52)_{c}$ \\
\hline & Klein & $4,53(1,43)_{a}$ & $3,22(1,39)_{b}$ & $4,49(I, 44)_{a}$ \\
\hline \multirow{2}{*}{$\begin{array}{l}\text { Eerder slacht- } \\
\text { offerschap }\end{array}$} & $\mathrm{Ja}$ & $4,39(1,42)_{\mathrm{a}}$ & $2,99(1,37)_{c}$ & $4,29(1,59)_{a}$ \\
\hline & Nee & $4,69(1,35)_{b}$ & $3,50(1,40)_{d}$ & $4,39(1,36)_{a}$ \\
\hline \multirow[t]{3}{*}{ Frequentie van uitgaan } & $\begin{array}{l}\text { Ongeveer } \\
\text { één keer per } \\
\text { maand of } \\
\text { minder }\end{array}$ & $4,56(I, 44)_{a}$ & $3,32(1,39)_{b}$ & $4,39(1,39)_{a}$ \\
\hline & $\begin{array}{l}\text { Ongeveer } \\
\text { eens per } \\
\text { twee weken }\end{array}$ & $4,63(1,32)_{a}$ & $3,19(1,34)_{b}$ & $4,42(I, 44)_{a}$ \\
\hline & $\begin{array}{l}\text { Ongeveer } \\
\text { één keer per } \\
\text { week of } \\
\text { meer }\end{array}$ & $4,40(I, 49)_{a}$ & $3,12(1,45)_{b}$ & $4,32(I, 59)_{a}$ \\
\hline
\end{tabular}

Noot: Vertrouwen is gemeten op een schaal van I (helemaal niet) tot 7 (heel erg). Gemiddelden met een verschillend subscript verschillen significant van elkaar tussen groepen (verticaal) en tussen actoren (horizontaal), met alle p's $<, 013$.

actoren is en hoe het vertrouwen is 'verdeeld' tussen de verschillende actoren. Tevens werd gekeken naar de mate waarin het vertrouwen in de politie, portiers en cameratoezicht verschilt tussen groepen, gebaseerd op demografische en contextuele factoren. Het huidige onderzoek baseert zich op data verkregen uit een enquête verspreid onder scholieren en studenten die onderwijs volgen in Utrecht en Rotterdam ( $\mathrm{n}=894)$.

In het algemeen laten resultaten zien dat participanten bovengemiddeld vertrouwen hebben in zowel politie als portiers, maar ondergemiddeld vertrouwen in cameratoezicht. Dit lijkt de kritische kanttekeningen omtrent de steun voor cameratoezicht, zoals naar voren komt in de literatuur, enigszins te ondersteu- 
nen. ${ }^{48}$ Met het vertrouwen in zowel de politie als portiers boven het gemiddelde van de beoordelingsschalen lijken de resultaten ook in overeenstemming met eerder onderzoek waarbij deelnemers verklaarden dat ze algemeen vertrouwen hadden in zowel politie als private beveiliging. ${ }^{49}$

Toch laten de resultaten ook zien dat participanten over het algemeen meer vertrouwen hebben in de politie dan in portiers. Dit zou te maken kunnen hebben met het imago van de private beveiligingssector: er lijkt meer scepsis rond het imago van private beveiliging te zijn dan rond het imago van de politie. ${ }^{50}$ Tegelijkertijd zien we een professionalisering van de private beveiligingssector door middel van investeringen in regelgeving, educatie en licenties, hetgeen zou kunnen verklaren waarom de mate van vertrouwen in portiers wel bovengemiddeld is. ${ }^{51}$

Wanneer rekening gehouden wordt met verschillende demografische en contextuele kenmerken, dan zien we tevens meer diversiteit in de beoordeling van de toezichtsactoren. Het algemene verschil in vertrouwen tussen politie en portiers wordt bijvoorbeeld versterkt wanneer we rekening houden met geslacht: mannen tonen het grootste verschil in vertrouwen tussen politie en portiers. Dit verschil wordt met name gedreven door de bevinding dat mannen minder vertrouwen hebben in portiers dan vrouwen, hetgeen in eerdere literatuur ook gevonden is, ${ }^{52}$ maar een gelijke mate van vertrouwen in de politie. Er werd tevens gevonden dat vrouwen minder vertrouwen tonen in cameratoezicht dan mannen. Dit lijkt in overeenstemming met eerdere literatuur, waarin gevonden wordt dat vrouwen zich zorgen maken over de mogelijkheid dat camera's juist als instrument voor intimidatie, zoals voyeurisme, gebruikt kunnen worden. ${ }^{53}$ Daarnaast tonen resultaten aan dat het vertrouwen in de politie lager is onder slachtoffers en onder mensen met een migratieachtergrond, hetgeen tevens veelvuldig in eerdere literatuur is geconstateerd. ${ }^{54}$ Het valt ook op dat de mate van vertrouwen in cameratoezicht lager is voor slachtoffers dan niet-slachtoffers. Een mogelijke verklaring hiervoor is dat zij het gevoel hebben niet goed geholpen te zijn door cameratoezicht in een eerder uitgaansincident. Eerder onderzoek toont bijvoorbeeld aan dat cameratoezicht als nuttig wordt beschouwd in de nasleep van een incident, maar niet zozeer tijdens het incident. ${ }^{55}$ Dit vormt tevens een verklaring voor de meer algemene bevinding dat er een lagere mate van institutioneel vertrouwen is in cameratoezicht dan in politie en portiers. Overkoepelend kan geconcludeerd

Ellis e.a. 2006; Trimek 2016; Webster 2009.

Saarikkomäki 2017.

K. Livingstone \& J. Hart, 'The wrong arm of the law? Public images of private security', Policing and Society 2003, 13, p. 159-170.

Thumala e.a. 2011.

Nalla \& Heraux 2003.

H. Koskela, 'Video surveillance, gender, and the safety of public urban space: "Peeping Tom" goes high tech?', Urban Geography 2002, p. 257-278.

Voor een overzicht, zie Brown \& Benedict 2002.

J. Brands, T. Schwanen \& I. van Aalst, 'What are you looking at? Visitors' perspectives on CCTV in the night-time economy', European Urban and Regional Studies 2016, 23, p. 23-39; Ellis e.a. 2013. 
worden dat vorenstaande resultaten het signaal afgeven dat er in de toepassing van toezichtsactoren goed nagedacht moet worden met welk doel, en voor welke groep, het toezicht ingezet wordt. Dat betekent enerzijds maatwerk. Anderzijds, om zulk beleid nader vorm te geven en te verankeren in achterliggende mechanismen, dient toekomstig onderzoek uit te wijzen waarom deze groepen tot een verschillende waardering van toezicht komen.

Bij de hiervoor gegeven resultaten dient een kanttekening gemaakt te worden met betrekking tot de algemeenheid van onze vertrouwensitems. Dat wil zeggen, de huidige items zijn gericht op het meten van institutioneel vertrouwen, maar of dit specifiek terugslaat op bepaalde normen en waarden, effectiviteit, fairness of andere gerelateerde percepties is niet met zekerheid te zeggen. ${ }^{56}$ Ondanks het vorenstaande hebben we er om verschillende redenen toch voor gekozen om met deze items te werken. Allereerst omdat er, voor zover bij ons bekend, geen gevalideerde schalen zijn die vertrouwen tussen toezichtsactoren meten en die we daarmee voor het huidige onderzoek hadden kunnen gebruiken. ${ }^{57}$ Het was daarbij ook niet ons onderzoeksdoel om een dergelijke schaal te ontwikkelen. Omdat ons belangrijkste doel is om het vertrouwen in verschillende actoren te vergelijken, hebben we geprobeerd items op te nemen die zo'n vergelijking mogelijk maken. Deze vergelijking betreft een unieke invalshoek die in eerder wetenschappelijk onderzoek mist. Ten tweede hebben we er bewust voor gekozen om in ieder geval meer dan één item te gebruiken om vertrouwen te meten. Dit in tegenstelling tot veel ander onderzoek naar vertrouwen in toezichtsactoren. ${ }^{58}$

Onze bevinding dat vertrouwen verschilt tussen actoren is tevens belangrijk tegen de achtergrond van de waargenomen toename van toezicht in stedelijke, openbare ruimten. Actoren anders dan de politie vervullen steeds vaker rollen die traditioneel gezien tot de taken van de politie behoorden, terwijl daarbij beperkt rekening gehouden wordt met de mate van vertrouwen, en als consequentie het draagvlak voor de actor. Dit roept niet alleen vragen op in de zin van de wenselijkheid van dergelijke 'toezichtsoverdrachten', het stelt ook een kritisch punt in het kader van legitimiteit. Zoals eerder aangegeven, een laag vertrouwen in een actor zou een bedreiging kunnen vormen voor de mate waarin iemand bereid is medewerking te verlenen en daarmee de mate waarin de actor in staat is om controle uit te oefenen. ${ }^{59}$ In ons onderzoek zien we dat dit mogelijk speelt voor CCTV, waar een ondergemiddeld vertrouwen voor wordt gevonden. Aan de andere kant, wat is dan voldoende vertrouwen? Wanneer kunnen we spreken van genoeg vertrouwen? Vragen waar we op basis van ons onderzoek geen sluitende antwoorden op kunnen geven, maar die wel het nader onderzoeken waard zijn.

56 L. Cao, 'Differentiating confidence in the police, trust in the police, and satisfaction with the police', Policing: An International Journal of Police Strategies \& Management 2015, 38, p. 239-249; Jackson \& Bradford 2010; Ren e.a. 2005.

57 Maar zie Moreira e.a. 2015 en Van Steden \& Nalla 2010 over private beveiliging.

58 Zie bijvoorbeeld Kääriäinen 2007 en K. Sindall, P. Sturgis \& W. Jennings, 'Public confidence in the police: A time-series analysis’, British Journal of Criminology 2012, 52, p. 744-764.

59 Jackson \& Bradford 2010; Tyler 2001. 
Op basis van het voorgaande zouden wij dan ook stellen dat pluralisering van toezicht en de verschuiving van toezichtsbevoegdheden naar actoren anders dan de politie dienen te worden geïmplementeerd met voldoende steun. Met name voor cameratoezicht is hier nog winst te behalen. Dit kan vooral een uitdaging zijn in de context van het nachtleven: hoewel het belangrijk is om ervoor te zorgen dat consumenten kunnen genieten van een veilig avondje uit, wordt er tegelijkertijd beargumenteerd dat de risico's, overmaat en ander 'gevaar' het uitgaansleven ook voor een deel opwindend maken. ${ }^{60}$ Wanneer mensen het gevoel zouden kunnen krijgen dat er sprake is van 'buitensporig' toezicht, dan zou dat in deze context juist voor een niet stimulerende en steriele omgeving kunnen zorgen.

60 R. Williams, 'Night spaces: Darkness, deterritorialization, and social control', Space and Culture 2008, 11, p. 514-532; P. Hubbard, 'Carnage! Coming to a town near you? Nightlife, uncivilized behaviour and the carnivalesque body’, Leisure Studies 2013, 32, p. 265-282. 